\title{
Measured, unmeasured, mismeasured, and unjustified pessimism: a review essay of Thomas Piketty's Capital in the twenty-first century
}

\author{
DEIRDRE NANSEN MCCLOSKEY \\ University of Illinois at Chicago
}

Keywords: Piketty, capitalism, inequality

JEL Classification: B40, B50, I32, N30, P10

Thomas Piketty has written a big book, 577 pages of text, 76 pages of notes, 115 charts, tables, and graphs, that has excited the left, worldwide. "Just as we said!" the leftists cry. "The problem is Capitalism and its inevitable tendency to inequality!" First published in French in 2013, an English edition was issued by Harvard University Press in 2014 to wide acclaim by columnists such as Paul Krugman, and a top position on the New York Times best-seller list. A German edition came out in late 2014, and Piketty-who must be exhausted by all this-worked overtime expositing his views to large German audiences. He plays poorly on TV, because he is lacking in humor, but he soldiers on, and the book sales pile up.

It has been a long time (how does "never" work for you?) since a technical treatise on economics has had such a market. An economist can only applaud. And an economic historian can only wax ecstatic. Piketty's great splash will undoubtedly bring many young economically interested scholars to devote their lives to the study of the past. That is good, because economic history is one of the few scientifically quantitative branches of economics. In economic history, as in experimental economics and a few other fields, the economists confront the evidence (as they do not for example in most macroeconomics or industrial organization or international trade theory nowadays). When you think about it, all evidence must be in the past, and some of the most interesting and scientifically relevant evidence is in the more 
or less remote past. And as the British economic historian John $\mathrm{H}$. Clapham said in 1922-rather in the style of Austrian economists, though he was a Marshallian-"the economist is, willy-nilly, an historian. The world has moved on before his conclusions are ripe" (Clapham 1922, 313). True, economic historians are commonly concerned with the past also for its own sake (I am, for example), and not only as a way of extrapolating into the future, which is Piketty's purpose. His book after all is about capital in the twenty-first century, which has barely gotten under way. But if you are going to be a scientific economist, or a scientific geologist or astronomer or evolutionary biologist, the past should be your present.

Piketty gives a fine example of how to do it. He does not get entangled as so many economists do in the sole empirical tool they are taught, namely, regression analysis on someone else's "data" (one of the problems is the word data, meaning "things given": scientists should deal in capta, "things seized"). Therefore he does not commit one of the two sins of modern economics, the use of meaningless "tests" of statistical significance (he occasionally refers to "statistically insignificant" relations between, say, tax rates and growth rates, but I am hoping he does not suppose that a large coefficient is "insignificant" because R. A. Fisher in 1925 said it was). Piketty constructs or uses statistics of aggregate capital and of inequality and then plots them out for inspection, which is what physicists, for example, also do in dealing with their experiments and observations. Nor does he commit the other sin, which is to waste scientific time on existence theorems. Physicists, again, don't. If we economists are going to persist in physics envy let us at least learn what physicists actually do. Piketty stays close to the facts, and does not, for example, wander into the pointless worlds of non-cooperative game theory, long demolished by experimental economics. He also does not have recourse to non-computable general equilibrium, which never was of use for quantitative economic science, being a branch of philosophy, and a futile one at that. On both points, bravissimo.

His book furthermore is clearly and unpretentiously, if dourly, written, and I imagine is also in its original French (Piketty is to be commended for following the old rule, not so popular among les français nowadays, that ce qui n'est pas clair n'est pas français, "that which is not clear is not French"). True, the book is probably doomed to be one of those more purchased than read. Readers of a certain age will 
remember Douglas Hofstadter's massive Gödel, Escher, Bach: an eternal golden braid (1979), which sat admired but unread on many a coffee table in the 1980s, and rather younger readers will remember Stephen Hawking's A brief history of time (1988). The Kindle company from Amazon keeps track of the last page of your highlighting in a downloaded book (you didn't know that, did you?). Using this data, the mathematician Jordan Ellenberg (2014) reckons that the average reader of the 655 pages of text and footnotes of Capital in the twenty-first century stops somewhere a little past page 26, where the highlighting stops, about the end of the Introduction. To be fair to Piketty, a buyer of the hardback rather than the Kindle edition is probably a more serious reader, and would go further. Still, holding the attention of the average New York Times reader for a little over 26 pages of dense economic argument, after which the book takes an honored place on the coffee table, testifies to Piketty's rhetorical skill, which I do admire. The book is endlessly interesting, at any rate if you find intricate numerical arguments interesting.

It is an honest and massively researched book. Nothing I shall sayand I shall say some hard things, because they are true and importantis meant to impugn Piketty's integrity or his scientific effort. The book is the fruit of a big collaborative effort of the Paris School of Economics, which he founded, associated with some of the brightest lights in the techno-left of French economics. Hélas, I will show that Piketty is gravely mistaken in his science and in his social ethics. But so are many economists and calculators, some of them my dearest friends.

\section{$\S$}

Reading the book is a good opportunity to understand the latest of the leftish worries about "capitalism", and to test its economic and philosophical strength. Piketty's worry about the rich getting richer is indeed merely "the latest" of a long series stretching back to Malthus and Ricardo and Marx. Since those founding geniuses of classical economics, a market-tested betterment (a locution to be preferred to "capitalism", with its erroneous implication that capital accumulation, not innovation, is what made us better off) has enormously enriched large parts of a humanity now seven times larger in population than in 1800 , and bids fair in the next fifty years or so to enrich everyone on the planet. Look at China and India (and stop saying, "But not everyone 
there has become rich"; they will, as the European history shows, at any rate by the ethically relevant standard of basic comforts denied to most people in England and France before 1800, or in China before its new beginning in 1978, or in India before 1991). And yet the left in its worrying routinely forgets this most important secular event since the invention of agriculture-the Great Enrichment of the last two centuries-and goes on worrying and worrying.

Here is a partial list of the worrying pessimisms, which each has had its day of fashion since the time, as the historian of economic thought Anthony Waterman put it,

Malthus's first [1798] Essay made land scarcity central. And so began a century-long mutation of 'political economy', the optimistic science of wealth, into 'economics', the pessimistic science of scarcity (Waterman 2012, 425, punctuation slightly modified).

Malthus worried that workers would proliferate and Ricardo worried that the owners of land would engorge the national product. Marx worried, or celebrated, depending on how one views historical materialism, that owners of capital would at least make a brave attempt to engorge it. (The classical economists are Piketty's masters, and his theory is self-described-before page 26-as the sum of Ricardo and Marx.) J. S. Mill worried, or celebrated, depending on how one views the sick hurry of modern life, that the stationary state was around the corner. Then economists, many on the left but some on the right, in quick succession from 1880 to the present-at the same time that market-tested betterment was driving real wages up and up and upcommenced worrying about, to name a few of the pessimisms concerning "capitalism" they discerned: greed, alienation, racial impurity, workers' lack of bargaining strength, workers' bad taste in consumption, immigration of lesser breeds, monopoly, unemployment, business cycles, increasing returns, externalities, under-consumption, monopolistic competition, separation of ownership from control, lack of planning, post-War stagnation, investment spillovers, unbalanced growth, dual labor markets, capital insufficiency (William Easterly calls it "capital fundamentalism"), peasant irrationality, capital-market imperfections, public choice, missing markets, informational asymmetry, third-world exploitation, advertising, regulatory capture, free riding, low-level traps, middle-level traps, path dependency, lack of competitiveness, consumerism, consumption externalities, irrationality, 
hyperbolic discounting, too big to fail, environmental degradation, underpaying of care, slower growth, and more.

One can line up the later items in the list, and some of the earlier ones revived à la Piketty or Krugman, with particular Nobel Memorial Prizes in Economic Science. I will not name here the men (all men, in sharp contrast to the method of Elinor Ostrom, Nobel 2009), but can reveal their formula. First, discover or rediscover a necessary condition for perfect competition or a perfect world (in Piketty's case, for example, a more perfect equality of income). Then assert without evidence (here Piketty does a great deal better than the usual practice) but with suitable mathematical ornamentation (thus Jean Tirole, Nobel 2014) that the condition might be imperfectly realized or the world might not develop in a perfect way. Then conclude with a flourish (here however Piketty falls in with the usual low scientific standard) that "capitalism" is doomed unless experts intervene with a sweet use of the monopoly of violence in government to implement anti-trust against malefactors of great wealth, or subsidies to diminishing-returns industries, or foreign aid to perfectly honest governments, or money for obviously infant industries, or the nudging of sadly childlike consumers, or, Piketty says, a tax on inequality-causing capital worldwide.

A feature of this odd history of fault-finding and the proposed statist corrections is that seldom does the economic thinker feel it necessary to offer evidence that his (mostly "his") proposed state intervention will work as it is supposed to, and almost never does he feel it necessary to offer evidence that the imperfectly attained necessary condition for perfection before intervention is large enough to have much reduced the performance of the economy in aggregate. (I repeat: Piketty exceeds the usual standard here.) Clapham made such a complaint in 1922 when the theorists were proposing on the basis of a diagram or two that government should subsidize allegedly increasing returns industries. The economists did not say how to attain the knowledge to do it, or how much their non-quantitative advice would actually help an imperfect government to get closer to the perfect society. The silence was discouraging, Clapham wrote sharply, to "the student not of categories but of things". It still is now, ninety years on. He chided Pigou thus: one looks into "The economics of welfare to find that, in nearly a thousand pages, there is not even one illustration of what industries are in which boxes [that is, in which theoretical categories], though many an argument begins, 'when conditions of 
diminishing returns prevail' or 'when conditions of increasing returns prevail', as if everyone knew when that was". He ventriloquizes the reply of the theorist imagining without quantitative oomph "those empty economic boxes", a reply heard still, with no improvement in its plausibility: "If those who know the facts cannot do the fitting, we [theorists finding grave faults in the economy] shall regret it. But our doctrine will retain its logical and, may we add, its pedagogic value. And then you know it goes so prettily into graphs and equations" (Clapham 1922, 311, 305, 312).

A rare exception to the record of not checking out what oomph an alleged imperfection might have was the Marxists Paul Baran's and Paul Sweezy's book Monopoly capital (1966), which actually tried (and honorably failed) to measure the extent of monopoly overall in the American economy. For most of the other worries on the list-such as that externalities require government intervention (as have declared in historical succession Pigou, Samuelson, and Stiglitz) - the economists so claiming that the economy is horribly malfunctioning and needs immediate, massive intervention from government advised by wise heads such as Pigou, Samuelson, and Stiglitz have not felt it was worth their scientific time to show that the malfunctioning matters much in aggregate. Piketty tries (and honorably fails). The sheer number of the briefly fashionable but never measured "imperfections" has taught young economists - they naïvely believe there must be facts behind the pretty theorems in their textbooks-to believe that market-tested betterment has worked disgracefully badly, when all the quantitative instruments agree that since 1800 it has worked spectacularly well.

By contrast, economists such as Arnold Harberger and Gordon Tullock claiming on the contrary that the economy works pretty well have done the factual inquiry, or have at least suggested how it might be done (see, e.g., Harberger 1954; Tullock 1967). The performance of Pigou, Samuelson, Stiglitz, and the rest on the left (admittedly in these three cases a pretty moderate "left") would be as though an astronomer proposed on some qualitative assumptions that the hydrogen in the sun would run out very, very soon, but did not bother to find out with serious observations and quantitative simulations roughly how soon the sad event was going to happen. Mostly in economic theory it has sufficed to show the mere direction of an "imperfection" on a blackboard (that is, it has sufficed to propound the "qualitative theorems" so disastrously recommended in Samuelson's Foundations) 
and then await the telephone call from the Swedish Academy early on an October morning.

One begins to suspect that the typical leftist-most of the graver worries have come from thereabouts, though not so very naturally, considering the great payoff of "capitalism" for the working classstarts with a root conviction that capitalism is seriously defective. The conviction is acquired at age 16 when he discovers poverty but has no intellectual tools to understand its source. I followed this pattern, and therefore became for a time a Joan-Baez socialist. Then the lifelong "good social democrat", as he describes himself (and as I for a while described myself), in order to support the now deep-rooted conviction, looks around when he has become a professional economist for any qualitative indication that in some imagined world the conviction would be true, without bothering to attach numbers drawn from our own world (of which, I say yet again, our Piketty can not be accused). It is the utopianism of good-hearted leftward folk who say, "Surely this wretched society, in which some people are richer and more powerful than others, can be greatly improved. We can do much, much better!" The utopianism springs from the logic of stage theories, conceived in the eighteenth century as a tool with which to fight traditional society, as in The wealth of nations, among lesser books.

True, the right can be accused of utopianism as well, when it asserts without evidence, as do some of the older-model Austrian economists, and as do some of the Chicago School who have lost their taste for engaging in serious testing of their truths, that we live already in the very best of all possible worlds. Yet admitting that there is a good deal of blame to spread around, the leftward refusal to quantify about the system as a whole seems to me more prevalent and more dangerous. I have a beloved and extremely intelligent Marxist friend who says to me, "I hate markets!" I reply, "But Jack, you delight in searching for antiques in markets". "I don't care. I hate markets!” The Marxists in particular have worried in sequence that the typical European worker would be immiserized, for which they had little evidence, then that he would be alienated, for which they had little evidence, then that the typical Third-World-periphery worker would be exploited, for which they had little evidence. Recently the Marxists and the rest of the left have commenced worrying about the environment, on what the late Eric Hobsbawm called with a certain distaste natural in an old Marxist "a much more middle-class basis" (Hobsbawm 2011, 416). We await 
their evidence, and their proposals for what to do about it, other than returning to Walden Pond and the life of 1800.

Long ago I had a nightmare. I am not much subject to them, and this one was vivid, an economist's nightmare, a Samuelsonian one. What if every single action had to be performed exactly optimally? Maximize Utility subject to Constraints. Max U s.t.C. Suppose, in other words, that you had to reach the exact peak of the hill of happiness subject to constraints with every single reaching for the coffee cup or every single step in the street. You would of course fail in the assignment repeatedly, frozen for fear of the slightest deviation from optimality. In the irrational way of nightmares, it was a chilling vision of what economists call rationality. A recognition of the impossibility of exact perfection lay, of course, behind Herbert Simon's satisficing, Ronald Coase's transaction costs, George Shackle's and Israel Kirzner's reaffirmation of Yogi Berra's wisdom: "It's tough to make predictions, especially about the future".

We young American economists and social engineers in the 1960s, innocent as babes, were sure we could attain predictable perfection. "Fine tuning" we called it. It failed, as perfection must. The political scientist John Mueller (1999) made the point that we should be seeking instead merely the "pretty good"-which would require some fact-based sense that we are not too terribly far from optimality in, say, Garrison Keillor's imagined Lake Wobegon, Minnesota in which Ralph's Pretty Good Grocery is in its advertising comically modest and Scandinavian ("If you can't find it at Ralph's, you probably don't need it anyway"). Mueller reckons that capitalism and democracy as they actually, imperfectly are in places like Europe or its offshoots are pretty good. The "failures" to reach perfection in, say, the behavior of Congress or the equality of the distribution of income in the U.S.A., Mueller reckons, are probably not large enough to matter all that much to the performance of the polity or the economy. They are good enough for Lake Wobegon. And driving across town to buy at the Exact Perfection Store, staffed by economic theorists specialized in finding failures in the economy without measuring them, often leads to consequences you probably do not need.

At least, then, Piketty is a serious quantitative scientist, unlike the other boys playing in the sandboxes of statistics of significance and theorems of existence and unmeasured imperfections in the economy and the setting of impossible tasks (unhappily in this last respect he 
joins the boys and their sandcastles) for an imperfect government. Indeed, Piketty declares that:

it is important to note that [...] the main source of divergence [of the incomes of the rich compared with the poor] in my theory has nothing to do with any market imperfection [note: possible governmental imperfections are off the Piketty table]. Quite the contrary: the more perfect the capital market (in the economist's sense) the more likely [the divergence] (p. 27; compare p. 573).

That is, like Ricardo and Marx and Keynes, he thinks he has discovered what the Marxists call a "contradiction" (p. 571), that is, an unhappy consequence of the very perfection of "capitalism". Yet all the worries from Malthus to Piketty, from 1798 to the present, share an underlying pessimism, whether about imperfection in the capital market or about the behavioral inadequacies of the individual consumer or about the Laws of Motion of a Capitalist Economy-this in the face of the largest enrichment that humans have ever witnessed. During the pretty good history of 1800 to the present the economic pessimists on the left have nonetheless been subject to nightmares of terrible, terrible failures

Admittedly, such pessimism sells. For reasons I have never understood, people like to hear that the world is going to hell, and become huffy and scornful when some idiotic optimist intrudes on their pleasure. Yet pessimism has consistently been a poor guide to the modern economic world. We are gigantically richer in body and spirit than we were two centuries ago. In the next half century-if we do not kill the goose that lays the golden eggs by implementing leftwing schemes of planning and redistribution or rightwing schemes of imperialism and warfare, as we did in many places, 1914-1989, following the advice of the clerisy that markets and democracy are terribly faulty - we can expect the entire world to match Sweden or France.

\section{$\S$}

Piketty's central theme is the force of interest on inherited wealth, causing, he claims, inequality of income to increase. In 2014 he declared to the BBC's Evan Davis in an interview that "money tends to reproduce itself", a complaint about money and its interest repeatedly made in the 
West since Aristotle. As the Philosopher said of some men, "the whole idea of their lives is that they ought either to increase their money without limit, or at any rate not to lose it [...]. The most hated sort [of increasing their money], [...] is usury, which makes a gain out of money itself" (Aristotle Politics, Book I).

Piketty's (and Aristotle's) theory is that the yield on capital usually exceeds the growth rate of the economy, and so the share of capital's returns in national income will steadily increase, simply because interest income-what the presumably rich capitalists get and supposedly manage to cling to and supposedly reinvest-grows faster than the income the whole society is getting. Aristotle and his followers, such as Aquinas and Marx and Piketty, were much concerned with such "unlimited" gain. The argument is, you see, very old and very simple. Piketty ornaments it a bit with some portentous accounting about capital-output ratios and the like, producing his central inequality about inequality: so long as $\boldsymbol{r}>\boldsymbol{g}$, where $\boldsymbol{r}$ is the return on capital and $\boldsymbol{g}$ is the growth rate of the economy, we are doomed to ever increasing rewards to rich capitalists while the rest of us poor suckers fall relatively behind. The merely verbal argument I just gave, however, is conclusive, so long as the factual assumptions are near-enough true: namely, only rich people have capital; human capital does not exist; the rich reinvest their returns-they never lose it to sloth or someone else's creative destruction; inheritance is the main mechanism, not creativity raising $\boldsymbol{g}$ for the rest of us just when it results in $\boldsymbol{r}$ shared by us all; and we care ethically only about the Gini coefficient, not the condition of the working class.

Notice one aspect of that last: in Piketty's tale the rest of us fall only relatively behind the ravenous capitalists. The focus on relative wealth or income or consumption is one serious problem in the book. Piketty's vision of a "Ricardian Apocalypse", as he calls it, leaves room for the rest of us to do very well indeed, most non-apocalyptically, as in fact since 1800 we have. What is worrying Piketty is that the rich might possibly get richer, even though the poor get richer too. His worry, in other words, is purely about difference, about the Gini coefficient, about a vague feeling of envy raised to a theoretical and ethical proposition.

Another serious problem is that $\boldsymbol{r}$ will almost always exceed $\boldsymbol{g}$, as anyone can tell you who knows about the rough level of interest rates on invested capital and about the rate at which most economies have grown (excepting only China, recently, where contrary to Piketty's 
prediction, inequality has increased). If his simple logic is true, then the Ricardian Apocalypse looms, always. Let us therefore bring in the sweet and blameless and omni-competent government-or, even less plausibly, a world government-to implement "a progressive global tax on capital" (p. 27) to tax the rich. It is our only hope.

Yet in fact his own things ingeniously seized in his research, his capta, as he candidly admits without allowing the admission to relieve his pessimism, suggest that only in Canada, the U.S.A., and the U.K. has the inequality of income increased much, and only recently. "In continental Europe and Japan, income inequality today remains far lower than it was at the beginning of the twentieth century and in fact has not changed much since 1945" (p. 321, and Figure 9.6). Look, for example, at page 323, Figure 9.7, the top decile's share of income, 1900-2010 for the U.S.A., the U.K., Germany, France, and Sweden. In all those countries $\boldsymbol{r}>\boldsymbol{g}$. Indeed, it has been so, with rare exceptions, very occasionally, since the beginning of time. Yet after the redistributions of the welfare state were accomplished, by 1970, inequality of income did not much rise, Piketty admits, in Germany, France, and Sweden. In other words, Piketty's fears were not confirmed anywhere 1910 to 1980, nor anywhere in the long run at any time before 1800, nor anywhere in continental Europe and Japan since World War II, and only recently, a little, in the United States, the United Kingdom, and Canada (Canada, by the way, is never brought into his tests).

That is a very great puzzle if money tends to reproduce itself, always, evermore, as a general law governed by the Ricardo-plus-Marx inequality at the rates actually observed in world history. Yet inequality in fact goes up and down in great waves, for which we have evidence from many centuries ago down to the present which also does not figure in his tale (Piketty barely mentions the work of the economic historians Jeffrey Williamson and Peter Lindert (1980) documenting that inconvenient fact). According to his logic, once a Piketty-wave starts-as it would at any time you care to mention if an economy satisfied the almost-always-satisfied condition of the interest rate exceeding the growth rate of income-it would never stop. Such an inexorable logic means we should have been overwhelmed by an inequality-tsunami in $1800 \mathrm{CE}$ or in $1000 \mathrm{CE}$ or for that matter in 2000 BCE. At one point Piketty says just that: " $\boldsymbol{r}>\boldsymbol{g}$ will again become the norm in the twentyfirst century, as it had been throughout history until the eve of World War I" (p. 572, italics added; one wonders what he does with historically 
low interest rates right now, or the negative real interest rates in the inflation of the 1970s and 1980s). Why then did the share of the rich not rise anciently to 100 percent? At the least, how could the share be stable at, say, the 50 percent that in medieval times typified unproductive economies with land and landlords dominant? Sometimes Piketty describes his machinery as a "potentially explosive process" (p. 444), at other times he admits that random shocks to a family fortune mean that "it is unlikely that inequality of wealth will grow indefinitely, $[. .$.$] rather,$ the wealth distribution will converge toward a certain equilibrium" (p. 451). On the basis of the Forbes lists of the very rich, Piketty notes, for example, "several hundred new fortunes appear in [the $\$ 1$ billion to $\$ 10$ billion] range somewhere in the world almost every year" (p. 441). Which is it, Professor Piketty? 'Apocalypse' as you put it, or (what is in fact observed, roughly, with minor ups and downs) a steady share of rich people constantly dropping out of riches or coming into them, in evolutionary fashion? His machinery seems to explain nothing alarming, and at the same time does too much alarming.

The science writer Matt Ridley has offered a persuasive reason for the (slight) rise in inequality recently in Britain. "Knock me down with a feather", Ridley writes,

You mean to say that during three decades when the government encouraged asset bubbles in house prices; gave tax breaks to pensions; lightly taxed wealthy non-doms [that is, "non-domiciled", the citizens of other countries such as Saudi Arabia living in the U.K.]; poured money into farm subsidies [owned by landlords mainly rich]; and severely restricted the supply of land for housing, pushing up the premium earned by planning permission for development, the wealthy owners of capital saw their relative wealth increase slightly? Well, I'll be damned [...] [Seriously, now] a good part of any increase in wealth concentration since 1980 has been driven by government policy, which has systematically redirected earning opportunities to the rich rather than the poor (Ridley 2014).

In the United States, with its pervasive welfare payments and tax breaks for our good friends the very rich, such as the treatment of "carried interest" which made Mitt Romney a lot richer, one can make a similar case that the government, which Piketty expects to solve the alleged problem, is the cause. It was not "capitalism" that caused the recent and restricted blip, and certainly not market-tested betterment at the extraordinary rates of the past two centuries. 
The inconsequence of Piketty's argument, in truth, is to be expected from the frailties of its declared sources. Start by adopting a theory by a great economist, Ricardo, which failed entirely as a prediction. Landlords did not engorge the national product, contrary to what Ricardo confidently predicted. Indeed the share of land rents in national (and world) income fell heavily nearly from the moment Ricardo claimed it would steadily rise. The outcome resembles that for Malthus, whose prediction of population overwhelming the food supply was falsified nearly from the moment he claimed it would happen.

All right. Then combine Ricardo's with another theory by a less-great economist, Marx (yet the greatest social scientist of the nineteenth century; without compare though mistaken on almost every substantive point, and especially in his predictions). Marx supposed that wages would fall and yet profits would also fall and yet technological betterments would also happen. Such an accounting, as the Marxist economist Joan Robinson frequently pointed out, is impossible. At least one, the wages or the profits, has to rise if technological betterment is happening, as it so plainly was. With a bigger pie, someone has to get more. In the event what rose were wages on raw labor and especially a great accumulation of human capital, but capital owned by the laborers, not by the truly rich. The return to physical capital was higher than a riskless return on British or American government bonds, in order to compensate for the risk in holding capital (such as being made obsolete by betterment-think of your computer, obsolete in four years). But the return on physical capital, and on human capital, was anyway held down to its level of very roughly 5 to 10 percent by competition among the proliferating capitalists. Imagine our immiserization if the income of workers, because they did not accumulate human capital, and their societies had not adopted the accumulation of ingenuities since 1800, had experienced the history of stagnation since 1800 that the per-unit return to capital has. It is not hard to imagine, because workers earn such miserable incomes even now in places like Somalia and North Korea. Instead, since 1800 in the average rich country the income of the workers per person increased by a factor of about 30 (2,900 percent, if you please) and even in the world as a whole, including the still poor countries, by a factor of 10 (900 percent), while the rate of return to physical capital stagnated (McCloskey 2015, chapter 2).

Piketty does not acknowledge that each wave of inventors, entrepreneurs, and even routine capitalists find their rewards taken 
from them by entry, which is an economic concept he does not appear to grasp. His lack of grasp is a piece with his failure to understand supply responses, that is, how increased scarcity leads to the entry of new firms Look at the history of fortunes in department stores. The income from department stores in the late nineteenth century, in Le Bon Marché, Marshall Fields, and Selfridge's, was entrepreneurial. The model was then copied all over the rich world, and was the basis for little fortunes in Cedar Rapids, Iowa and Benton Harbor, Michigan. Then in the late twentieth century the model was challenged by a wave of discounters, and they then in turn by the Internet. The original accumulation slowly or quickly dissipates. In other words, the profit going to the profiteers is more or less quickly undermined by outwardshifting supply, if governmental monopolies and protectionisms of the sort Ridley noted in Britain do not intervene. The economist William Nordhaus (2004) has calculated that inventors and entrepreneurs nowadays earn in profit only 2 percent of the social value of their inventions. If you are Sam Walton that 2 percent earns you personally a great deal of money for introducing bar codes into stocking supermarket shelves. But 98 percent at the cost of 2 percent is nonetheless a pretty good deal for the rest of us. The gain from macadamized roads or vulcanized rubber, then modern universities, structural concrete, and the airplane, has enriched even the poorest among us.

Piketty, who does not believe in supply responses, focuses instead on the great evil of very rich people having seven Rolex watches by mere inheritance. Liliane Bettencourt, heiress to the L'Oréal fortune (p. 440), the third richest woman in the world, who "has never worked a day in her life, saw her fortune grow exactly as fast as that of [the admittedly bettering] Bill Gates". That is bad, Piketty says, which is his ethical philosophy in full.

The Australian economists Geoffrey Brennan, Gordon Menzies, and Michael Munger make a similar argument in a recent paper, written in advance of Piketty's book, that inheritance inter vivos of human capital is bound to exacerbate Gini-coefficient inequality because "for the first time in human history richer parents are having fewer children [...]. Even if the increased opulence continues, it will be concentrated in fewer and fewer hands" (Brennan, et al. 2014). The rich will send their one boy, intensively tutored in French and mathematics, to Sydney Grammar 
School and on to Harvard. The poor will dissipate what little they have among their supposedly numerous children.

But if on account of Adam Smith's hoped-for "universal opulence which extends itself to the lowest ranks of the people" all have access to excellent education-which is an ethically sensible object of social policy, unlike Gini-coefficient inequality, and has the additional merit of being achievable-and if the poor are so rich (because the Great Enrichment has been unleashed) that they, too, have fewer children, which is the case in, say, Italy, then the tendency to rising variance will be attenuated (see Smith 1776, book I, ch. 1, para. 10). The economist Tyler Cowen reminds me, further, that "low" birth rates also include "zero children", which would make lines die out-as indeed they often did even in well nourished royal families. Non-existent children, such as those of Grand Duke of Florence Gian Gastone de' Medici in 1737, cannot inherit, inter vivos or not. Instead their very numerous secondand third-cousins do.

And the effect of inherited wealth on children is commonly to remove their ambition, as one can witness daily on Rodeo Drive. Laziness-or for that matter regression to the mean of ability-is a powerful equalizer. "There always comes a time", Piketty writes against his own argument, "when a prodigal child squanders the family fortune" (p. 451), which was the point of the centuries-long struggle in English law for and against entailed estates. Imagine if you had access to ten million dollars at age 18, before your character was fully formed. It would have been an ethical disaster for you, as it regularly is for the children of the very rich. We prosperous parents of the Great Enrichment can properly worry about our children's and especially our grandchildren's incentives to such efforts as a Ph.D. in economics, or serious entrepreneurship, or indeed serious charity. However many diamond bracelets they have, most rich children, and maybe all our children in the riches that the Great Enrichment is extending to the lowest ranks of the people, will not suffer through a Ph.D. in economics. Why bother? David Rockefeller did (University of Chicago, 1940; and he did understand supply responses), but his grandfather was unusually lucky in transmitting born-poor values to his son John Jr. and then to his five John-Junior-begotten grandsons (though not to his one granddaughter in that line, Abby, who never worked a day in her life).

Because Piketty is obsessed with inheritance, moreover, he wants to downplay entrepreneurial profit, the market-tested betterment that has 
made the poor rich. It is again Aristotle's claim that money is sterile and interest is therefore unnatural. Aristotle was on this matter mistaken. It is commonly the case, contrary to Piketty, and setting aside the cheapening of our goods produced by the investments of their wealth by the rich, that the people with more money got their more by being more ingeniously productive, for the benefit of us all-getting that Ph.D., for example, or being excellent makers of automobiles or excellent writers of horror novels or excellent throwers of touchdown passes or excellent providers of cell phones, such as Carlos Slim of Mexico, the richest man in the world (with a little boost, it may be, from corrupting the Mexican parliament). That Frank Sinatra became richer than most of his fans was not an ethical scandal. The "Wilt Chamberlain" example devised by the philosopher Robert Nozick (Piketty mentions John Rawls, but not Nozick, who was Rawls's nemesis) says that if we pay voluntarily to get the benefit of clever CEOs or gifted athletes there is no further ethical issue. The unusually high rewards to the Frank Sinatras and Jamie Dimons and Wilt Chamberlains come from the much wider markets of the age of globalization and mechanical reproduction, not from theft. Wage inequality in the rich countries experiencing an enlarging gap of rich vs. poor, few though they are (Piketty's finding, remember), is mainly, he reports, caused by "the emergence of extremely high remunerations at the summit of the wage hierarchy, particularly among top managers of large firms". The emergence, note, has nothing to do with $\boldsymbol{r}>\boldsymbol{g}$.

\section{$\S$}

The technical flaws in the argument are pervasive. When you dig, you find them. Let me list two that I myself spotted. Other economists, I have heard, have spotted many more: google "Piketty". (I have not done the googling, since I do not want merely to pile on. I respect what he tried to accomplish, and he therefore deserves from me an independent evaluation.)

For example-a big flaw, this one-Piketty's definition of wealth does not include human capital, owned by the workers, which has grown in rich countries to be the main source of income, when it is combined with the immense accumulation since 1800 of capital in knowledge and social habits, owned by everyone with access to them. Therefore his laboriously assembled charts of the (merely physical and private) 
capital/output ratio are erroneous. They have excluded one of the main forms of capital in the modern world. More to the point, by insisting on defining capital as something owned nearly always by rich people, Piketty mistakes the source of income, which is chiefly embodied human ingenuity, not accumulated machines or appropriated land. He asserts somewhat mysteriously on page 46 that there are "many reasons for excluding human capital from our definition of capital". But he offers only one: "human capital cannot be owned by any other person". Yet human capital is owned precisely by the worker herself. Piketty does not explain why self-ownership without alienation permitted (à la Locke) is not ownership. If I own improved land, and the law prevents its alienation (as some collectivist laws do), why is it not capital? Certainly, human capital is "capital": it accumulates through abstention from consumption, it depreciates, it earns a market-determined rate of return, it can be made obsolete by creative destruction.

Once upon a time, to be sure, Piketty's world without human capital was approximately our world, that of Ricardo and Marx, with workers owning only their hands and backs, and the bosses and landlords owning all the other means of production. But since 1848 the world has been transformed by what is between the workers' ears. The result of excluding human capital from capital is to artificially force the conclusion Piketty wants to achieve, that inequality has increased, or will, or might, or is to be feared. One of the headings in chapter 7 declares that "capital [is] always more unequally distributed than labor". No, it is not. If human capital is included-the ordinary factory worker's literacy, the nurse's educated skill, the professional manager's command of complex systems, the economist's understanding of supply responses-the workers themselves in the correct accounting own most of the nation's capital, and Piketty's drama from 1848 falls to the ground.

The neglect of human capital on the Problems side of the book is doubly strange because on the Solutions side Piketty recommends education and other investments in human capital. Yet in his focus on raising the marginal product of unemployed workers by government program rather than by correcting the distortions that created the unemployment in the first place he joins most of the left, especially those with university jobs. Thus in South Africa the left proposes to carry on with high minimum wages and oppressive regulation, solving the unemployment problem governmentally generated by improving 
through the same government the education of unemployed South Africans. No one, left or right or libertarian, would want to complain about better education, especially if it falls from the sky at no opportunity cost-though we bleeding heart libertarians would suggest achieving it by some other means than by pouring more money into a badly functioning nationalized industry providing elementary education or into a higher education system grossly favoring the rich over the poor, as it does strikingly in France, by giving the rich student, better prepared, a tuition-free ride into the ruling class. In any case the "welove-education" ploy exempts the left from facing the obvious cause of unemployment in South Africa, namely, a sclerotic system of labormarket and other regulations in aid of the Congress of South African Trade Unions and against the wretchedly poor black South African sitting jobless with a small income subsidy in a hut in the back country of KwaZulu-Natal.

Piketty's book is by no means without good and interesting and technical economics. He offers an interesting theory (chapter 14), for example, that the very high CEO salaries we have nowadays in the U.K. and especially the U.S.A. are a result of the fall in marginal tax rates from their high levels during 1930-1970. In those halcyon days it was not so bright of the managers to pay themselves huge salaries which after all the government would take away on March 15. Once this disincentive was removed, Piketty plausibly argues, the managers could take advantage of the clubby character of executive-remuneration committees to go to town. And so Piketty recommends returning to 80 percent marginal income tax rates (p. 513). But wait. Technically speaking, if on ethical grounds we do not like high CEO salaries, why not legislate against them directly, using some more targeted tool than a massive intrusion into the economy? Or why not shame the executiveremuneration committees? Piketty does not say.

\section{$\S$}

The fundamental technical problem in the book, however, as I have hinted, is that Piketty the economist does not understand supply responses. Because he doesn't understand supply responses he thinks that any tightness in supply is permanent, which is how he gets his Ricardian Apocalypse and all our woe. In keeping with his position as a man of the left, he has a vague and confused idea about how markets 
work, and especially about how supply responds to higher prices. If he wants to offer pessimistic conclusions concerning "a market economy based on private property, if left to itself" (p. 571), he had better know what elementary economics, agreed to by all who have studied it enough to understand what it is saying, does in fact say about how a market economy based on private property behaves when left to itself.

Startling evidence of Piketty's misunderstanding occurs as early as page 6 . He begins by seeming to concede to his neoclassical opponents (he is I repeat a proud Classicist: Ricardo plus Marx).

To be sure, there exists in principle a quite simple economic mechanism that should restore equilibrium to the process [in this case the process of rising prices of oil or urban land leading to a Ricardian Apocalypse]: the mechanism of supply and demand. If the supply of any good is insufficient, and its price is too high, then demand for that good should decrease, which would lead to a decline in its price (p. 6, italics added).

The (English) words I italicize clearly mix up movement along a demand curve with movement of the entire curve, a first-term error at university. The correct analysis (we tell our first-year, first-term students at about week four) is that if the price is "too high" it is not the whole demand curve that "restores equilibrium" (though the high price in the short run does give people a reason to conserve on oil or urban land with smaller cars and smaller apartments, moving as they in fact do up along their otherwise stationary demand curves), but an eventually outward-moving supply curve. The supply curve moves out because entry is induced by the smell of super-normal profits in the medium and long run (which is the Marshallian definition of the terms). New oil deposits are discovered, new refineries are built, new suburbs are settled, new high-rises saving urban land are constructed, as has in fact happened massively since, say, 1973, unless government has restricted oil exploitation (usually on environmental grounds) or the building of high-rises (usually on corrupt grounds).

Piketty goes on-remember: it does not occur to him that high prices cause after a while the supply curve to move out; he thinks the high price will cause the demand curve to move in, leading to "a decline in price" (of the scarce item, oil or urban land) -"such adjustments might be unpleasant or complicated". To show his contempt for the ordinary working of the price system he imagines comically that "people should [...] take to traveling about by bicycle". The substitutions along a given 
demand curve, or one mysteriously moving in, "might also take decades, during which landlords and oil well owners might well accumulate claims on the rest of the population" (now he has the demand curve moving out, for some reason faster than the supply curve moves out) "so extensive that they could easily [on grounds not argued] come to own everything that can be owned, including" in one more use of the comical alternative, "bicycles, once and for all". Having butchered the elementary analysis of entry and of substitute supplies, which after all is the economic history of the world, he speaks of "the emir of Qatar" as a future owner of those bicycles, once and for all. The phrase must have been written before the recent and gigantic expansion of oil and gas exploitation in Canada and the United States. In short, he concludes triumphantly, having seen through the obvious silliness found among those rich-friendly neoclassical economists, "the interplay of supply and demand in no way rules out the possibility of a large and lasting divergence in the distribution of wealth linked to extreme changes in certain relative prices [...]. Ricardo's scarcity principle” (pp. 6-7).

I was so startled by the passage that I went to the French original and called on my shamefully poor French to make sure it was not a mistranslation. A charitable reading might say it was-very charitable indeed because after all the preparatory senselessness remains: "then demand [the whole demand curve?] for that good should decrease" (alors la demande pour ce bien doit baisser). Yet Piketty's English is much better than my French-he taught for a couple of years at MIT, and speaks educated English when interviewed. If he let stand the senselessness in the translation by Arthur Goldhammer (a mathematics Ph.D. who has since 1979 done fully 75 translations of books from the French-though admittedly this is his first translation of technical economics), especially in such an important passage, one has to assume that he thought it was fine economics, a penetrating, nay decisive, criticism of those silly native-English-or-German-speaking economists who think that supply curves move out in response to increased scarcity. (Yet again I urge a bit of charity: she who has never left a little senselessness in her texts, and especially in translations out of her native language, is invited to cast the first stone.) In the French version one finds, instead of the obviously erroneous English, "which should lead to a decline in its price", typical of the confused first-term student, the clause qui permettra de calmer le jeu, "which should permit some calming down", or more literally, "which would permit some calming of 
the play [of, in this case, supply and demand]". Calmer le jeu, though, is in fact sometimes used in economic contexts in French to mean heading off a price bubble. And what "calming down" could mean in the passage other than an economics-and-common-sense-denying fall in price without a supply response having taken place is hard to see. The rest of the passage does not support the charitable reading. The rest is uncontroversially translated, and spins out the conviction Piketty evidently has that supply responses do not figure in the story of supply and demand, which anyway is unpleasant and complicated-so much less so than, say, the state taking a radically larger share of national income in taxes, with its attendant inefficiencies, or the state encouraging the spurning of capitalist ownership in favor of "new forms of governance and shared ownership intermediate between public and private" (p. 573), with its attendant corruptions and lack of skin in the game.

Piketty, it would seem, has not read with understanding the theory of supply and demand that he disparages, such as in Smith (one sneering remark on p. 9), Say (ditto, mentioned in a footnote with Smith as optimistic), Bastiat (no mention), Walras (no mention), Menger (no mention), Marshall (no mention), Mises (no mention), Hayek (one footnote citation on another matter), Friedman (pp. 548-549, but only on monetarism, not the price system). He does not have the scientific standing to sneer at self-regulating markets (for example on p. 572), because he shows in this and many other passages that does not understand how they work, even in principle. It would be like someone attacking the theory of evolution (which is identical to the theory economics uses of entry and exit in self-regulating markets-the supply response-an early version of which inspired Darwin) without understanding natural selection or the Galton-Watson process or modern genetics.

In a way, it is not his fault. He was educated in France, and the French-style teaching of economics, against which the insensitivelynamed Post-Autistic Economics (PAE) movement by economics students in France was directed, is abstract and Cartesian, and never teaches the ordinary price theory that one might use to understand the oil market, 1973 to the present. ${ }^{1}$ Because of supply responses, never considered in books by non-economists such as Paul Ehrlich's The population bomb

\footnotetext{
1 On the other hand, the French economist Bernard Guerrien who inspired the movement has his own problems, see McCloskey 2006b.
} 
(1968) or by economists who do not understand elementary economics, the real price of oil, for example, has fallen since 1980.

More deeply, Piketty's "structural" thinking characterizes the left, and characterizes too the economic thinking of physical and biological scientists when they venture into economic issues. It is why the magazine Scientific American half a century ago loved input-output analysis (which was the love also of my own youth) and regularly publishes fixed-coefficient arguments about the environment by physical and biological scientists. The non-economic scientists declare: "We have such-and-such a structure in existence, which is to say the accounting magnitudes presently existing, for example the presently known reserves of oil". Then, ignoring that search for new reserves is in fact an economic activity, they calculate the result of rising "demand" (that is, quantity demanded, not distinguished from the whole demand curve), assuming no substitutions, no along-the-demand curve reaction to price, no supply reaction to price, no second or third act, no seen and unseen, such as an entrepreneurial response to greater scarcity. In the mid-nineteenth century it was Marx's scientific procedure, too, and Piketty follows it.

\section{$\S$}

Beyond technical matters in economics, the fundamental ethical problem in the book is that Piketty has not reflected on why inequality by itself would be bad. The Liberal Lady Glencora Palliser (née M'Cluskie) in Anthony Trollope's political novel Phineas Finn (1867-1868) declares that "Making men and women all equal. That I take to be the gist of our political theory", as against the Conservative delight in rank and privilege. But one of the novel's radicals in the Cobden-Bright-Mill mold ("Joshua Monk") sees the ethical point clearer: "Equality is an ugly word, and frightens", as indeed it had long frightened the political class in Britain, traumatized by wild French declarations for égalité, and by the example of American egalitarianism (well... egalitarianism for male, straight, white, Anglo, middle-aged, non-immigrant, New-England, mainline Protestants). The motive of the true Liberal, Monk continues, should not be equality but "the wish of every honest [that is, honorable] man [...] to assist in lifting up those below him" (Trollope 1867-1869, vol. I, 126, 128). Such an ethical goal was to be achieved, says Monk the libertarian liberal (as Richard Cobden and John Bright and John Stuart 
Mill were, and Bastiat in France at the time, and in our times Hayek and Friedman, or for that matter M'Cluskie), not by direct programs of redistribution, nor by regulation, nor by trade unions, but by free trade and tax-supported compulsory education and property rights for women-and in the event by the Great Enrichment, which finally in the late nineteenth century started sending real wages sharply up, Europewide, and then worldwide.

The absolute condition of the poor has been raised overwhelmingly more by the Great Enrichment than by redistribution. The economic historians Ian Gazeley and Andrew Newell noted in 2010 "the reduction, almost to elimination, of absolute poverty among working households in Britain between 1904 and 1937". "The elimination of grinding poverty among working families", they show, "was almost complete by the late thirties, well before the Welfare State". Their Chart 2 exhibits weekly income distributions in 1886 prices at 1886, 1906, 1938, and 1960, showing the disappearance of the classic line of misery for British workers, "round about a pound a week" (Gazeley and Newell 2010, Abstract, p. 19, and Chart 2 on p. 17).

To be sure, it is irritating if a super rich woman buys a $\$ 40,000$ watch. The purchase is ethically objectionable. She should be ashamed. She should be giving her income in excess of an ample level of comfort-two cars, say, not twenty, two houses, not seven, one yacht, not five-to effective charities. Andrew Carnegie (1889) enunciated the principle that "a man who dies thus rich dies disgraced" Carnegie gave away his entire fortune (well, at death, after enjoying a castle in his native Scotland and a few other baubles). But that many rich people act in a disgraceful fashion does not automatically imply that the government should intervene to stop it. People act disgracefully in all sorts of ways. If our rulers were assigned the task in a fallen world of keeping us all wholly ethical, the government would bring all our lives under its fatherly tutelage, a real nightmare approximately achieved before 1989 in East Germany and now in North Korea.

One could argue, again, as Piketty does, that growth depends on capital accumulation-not on a new ideology and the bettering ideas that such an ideology encouraged, and certainly not on an ethics supporting the ideology. Piketty, like many American High Liberals, European Marxists, and conservatives everywhere, is annoyed precisely by the ethical pretension of the modern CEOs. The bosses, he writes, justify their economic success by placing "primary emphasis on their 
personal merit and moral qualities, which they described [in surveys] using term such as rigor, patience, work, effort, and so on (but also tolerance, kindness, etc.)" (p. 418). As the economist Donald Boudreaux puts it,

Piketty prefers what he takes to be the more honest justifications for super-wealth offered by the elites of the novels of [the conservatives] Austen and Balzac, namely, that such wealth is required to live a comfortable lifestyle, period. No self-praise and psychologically comforting rationalizations by those early-nineteenth century squires and their ladies! (Boudreaux, personal correspondence, 2014)

Piketty sneers from a conservative-progressive height that "the heroes and heroines in the novels of Austen and Balzac would never have seen the need to compare their personal qualities to those of their servants". To which Boudreaux replies,

Yes, well, bourgeois virtues were not in the early nineteenth century as widely celebrated and admired as they later came to be celebrated and admired. We should be pleased that today's [very] high-salaried workers brag about their bourgeois habits and virtues, and that workers-finally! - understand that having such virtues and acting on them is dignified (Boudreaux 2014).

The theory of great wealth espoused by the peasants and proletariat and their soi-disant champions among the leftish clerisy is non-desert by luck or theft. The theory of great wealth espoused by the aristocracy and their champions among the rightish clerisy is desert by inheritance, itself to be justified by ancient luck or theft, an inheritance we aristoi of course should collect without psychologically comforting rationalizations. The theory of great wealth espoused by the bourgeoisie and by its friends the liberal economists, on the contrary, is desert by virtue of supplying ethically, without violence, what people are willing to buy.

The bourgeois virtues are doubtless exaggerated, especially by the bourgeoisie, and sometimes even by its friends. But for the rest of us the results of virtue-bragging have not been so bad. Think of the later plays of Ibsen, the pioneering dramatist of the bourgeois life. The bank manager, Helmer, in A doll house (1878) describes a clerk caught in forgery as "morally lost", having a "moral breakdown" (Ibsen 1879, 132). Helmer's speech throughout the play is saturated with an ethical rhetoric we are accustomed to calling "Victorian". But Helmer's wife 
Nora, whose rhetoric is also ethically saturated, commits the same crime as the clerk's. She commits it, though, in order to save her husband's life, not as the clerk does for amoral profit. By the end of the play she leaves Helmer, a shocking move among the Norwegian bourgeoisie of 1878 , because she suddenly realizes that if he knew of her crime he would not have exercised the loving ethics of protecting her from the consequences of a forgery committed for love, not for profit. An ethical bourgeoisie-which is what all of Ibsen's plays after 1871 explore, as did later the plays of Arthur Miller-has complicated duties. The bourgeoisie goes on talking and talking about virtue, and sometimes achieves it.

The original and sustaining causes of the modern world, I would argue contrary to Piketty's sneers at the bourgeois virtues, were indeed ethical, not material (see McCloskey forthcoming). They were the widening adoption of two mere ideas, the new and liberal economic idea of liberty for ordinary people and the new and democratic social idea of dignity for them. The two linked and preposterous ethical ideas-the single word for them is "equality", of respect and before the law-led to a paroxysm of betterment. The word "equality", understand, is not to be taken, in the style of some in the French Enlightenment, as equality of material outcome. The French definition is the one the left and the right unreflectively assume nowadays in their disputes: "You didn't build that without social help, so there's no justification for unequal incomes"; "You poor folk just aren't virtuous enough, so there's no justification for your claim of equalizing subsidies". The more fundamental definition of equality, though, praised in the Scottish Enlightenment after the Scots awoke from their dogmatic slumber, is the egalitarian opinion people have of each other, whether street porter or moral philosopher (see Peart and Levy 2008). ${ }^{2}$ The moral philosopher Smith, a pioneering egalitarian in this sense, described the Scottish idea as "allowing every man to pursue his own interest his own way, upon the liberal plan of equality, liberty and justice" (Smith 1776, book IV, ch. 9, p. 664).

Forcing in an illiberal way the French style of equality of outcome, cutting down the tall poppies, envying the silly baubles of the rich, imagining that sharing income is as efficacious for the good of the poor

\footnotetext{
${ }^{2}$ Kim Priemel of Humboldt University of Berlin suggests to me that "equity" would be a better word for the Scottish concept. But I do not want to surrender so easily an essentially contested concept such as French égalité, which indeed in its original revolutionary meaning was more Scottish than what I am calling "French".
} 
as are equal shares in a pizza, treating poor people as sad children to be nudged or compelled by the experts of the clerisy, we have found, has often had a high cost in damaging liberty and slowing betterment. Not always, but often.

It would be a good thing, of course, if a free and rich society following Smithian liberalism produced a French and Pikettyan equality. In fact-old news, surprising to some, and to Piketty-it largely has, by the only ethically relevant standard, that of basic human rights and basic comforts in antibiotics and housing and education, compliments of the liberal and Scottish plan. Introducing the Scottish plan, as in Hong Kong and Norway and France itself, has regularly led to an astounding betterment and to a real equality of outcome-with the poor acquiring automobiles and hot-and-cold water at the tap that were denied in earlier times even to the rich, and acquiring political rights and social dignity that were denied in earlier times to everyone except the rich.

Even in the already-advanced countries in recent decades there has been no complete stagnation of real incomes for ordinary people. You will have heard that "wages are flat" or that "the middle class is shrinking". But you also know that you should not believe everything you read in the papers. This is not to say that no one in rich countries such as the United States is unskilled, addicted, badly parented, discriminated against, or simply horribly unlucky. George Packer's recent The unwinding: an inner history of the new America (2013) and Barbara Ehrenreich's earlier Nickel and dimed: on (not) getting by in America (2001) carry on a long and distinguished tradition of telling the bourgeoisie about the poor that goes back to James Agee and Walker Evans, Let us now praise famous men (1944), George Orwell, The road to Wigan Pier (1937), Jack London, The people of the abyss (1903), Jacob Riis, How the other half lives: studies among the tenements of New York (1890), and the fount, Friedrich Engels, The condition of the working class in England (1845). They are not making it up. Anyone who reads such books is wrenched out of a comfortable ignorance about the other half. In fictional form one is wrenched by Steinbeck's The grapes of wrath (1939) or Farrell's Studs Lonigan (1932-1935) or Wright's Native son (1940), or in Europe, among many observers of the Two Nations, Zola's Germinal (1885), which made many of us into socialists. The wrenching is salutary. It is said that Winston Churchill, scion of the aristocracy, believed that most English poor people lived in rose-covered 
cottages. He could not imagine back-to-backs in Salford, with the outhouse at the end of the row. Wake up, Winston.

But waking up does not imply despairing, or introducing faux policies that do not actually help the poor, or proposing the overthrow of the System, if the System is in fact enriching the poor over the long run, or at any rate enriching the poor better than those other systems that have been tried from time to time. Righteous, if inexpensive, indignation inspired by survivor's guilt about alleged "victims" of something called "capitalism" and by envious anger at the silly consumption by the rich do not invariably yield betterment for the poor. Remarks such as "there are still poor people" or "some people have more power than others", though claiming the moral high-ground for the speaker, are not deep or clever. Repeating them, or nodding wisely at their repetition, or buying Piketty's book to display on your coffee table, does not make you a good person. You are a good person if you actually help the poor. Open a business. Arrange mortgages that poor people can afford. Invent a new battery. Vote for better schools. Adopt a Pakistani orphan. Volunteer to feed people at Grace Church on Saturday mornings. The offering of faux, counterproductive policies that in their actual effects reduce opportunities for employment, or the making of indignant declarations to your husband after finishing the Sunday New York Times Magazine, does not help the poor.

The economy and society of the United States are not in fact unwinding, and people are in fact getting by better than they did before. The children of the sharecropping families in Hale County, Alabama whom Agee and Evans objectified, to the lasting resentment of the older members of the families, are doing pretty well, holding jobs, many of their children going to college (Whitford 2005). That even over the long run there remain some poor people does not mean that the system is not working for the poor, so long as their condition is continuing to improve, as it is, contrary to the newspaper stories and the pessimistic books, and so long as the percentage of the desperately poor is heading towards zero, as it is. That people still sometimes die in hospitals does not mean that medicine is to be replaced by witch doctors, so long as death rates are falling and so long as the death rate would not fall under the care of the witch doctors.

And poverty is indeed falling, even recently, even in already rich countries. If income is correctly measured to include better working conditions, more years of education, better health care, longer 
retirement years, larger poverty-program subsidies, and above all the rising quality of the larger number of goods, the real income of the poor has risen, if at a slower pace than in the 1950s-which followed the calamitous time-outs of the Great Depression and the War (Boudreaux and Perry 2013). The economist Angus Deaton notes that "once the rebuilding is done [as it was in, say, 1970], new growth relies on inventing new ways of doing things and putting them into practice, and this turning over of virgin soil is harder than re-plowing an old furrow" Deaton 2013, 231). Nor are the world's poor paying for the growth. The economists Xavier Sala-i-Martin and Maxim Pinkovsky report on the basis of detailed study of the individual distribution of income-as against comparing distributions nation-by-nation-that:

World poverty is falling. Between 1970 and 2006, the global poverty rate [defined in absolute, not relative, terms] has been cut by nearly three quarters. The percentage of the world population living on less than $\$ 1$ a day (in PPP-adjusted 2000 dollars) went from 26.8\% in 1970 to 5.4\% in 2006 (Sala-i-Martin and Pinovsky 2010, see also Salai-Martin 2006).

It is important in thinking about the issues Piketty so energetically raises to keep straight what exactly is unequal. Physical capital and the paper claims to it are unequally owned, of course, although pension funds and the like do compensate to some degree. The yield on such portions of the nation's capital stock is the income of the rich, especially the rich-by-inheritance whom Piketty worries most about. But if capital is more comprehensively measured, to include increasingly important human capital such as engineering degrees and increasingly important commonly-owned capital such as public parks and modern knowledge (think: the Internet), the income yield on capital is less unequally owned, I have noted, than are paper claims to physical capital.

Further, consumption is much less unequally enjoyed than income is measured. A rich person owning seven houses might be thought to be seven times better off than a poor person with barely one. But of course she is not, since she can consume by occupying only one house at a time, and can consume only one pair of shoes at a time, and so forth. The diamond bracelet sitting un-worn at the bottom of her ample jewelry box is a scandal, since she could have paid the school fees of a thousand families in Mozambique with what she foolishly spent on the bauble last season in Cannes. She ought indeed to be ashamed to 
indulge such foolish expenditure. It is an important ethical issue, if not a public issue. But anyway the expenditure has not increased her actual, point-of-use consumption.

Further, and crucially, the consumption of basic capabilities or necessities is very much more equally enjoyed nowadays than the rest of consumption, or income, or capital, or physical wealth, and has become more and more equally so as the history of enriching countries proceeds. Therefore economic growth, however unequally it is accumulated as wealth or earned as income, is more egalitarian in its consumption, and by now is quite equal in consumption of necessities. As the American economist John Bates Clark predicted in 1901:

The typical laborer will increase his wages from one dollar a day to two, from two to four and from four to eight [which was accurate in real terms of per-person income down to 2012, though such a calculation does not allow for the radically improved quality of goods and services since 1901]. Such gains will mean infinitely more to him than any possible increase of capital can mean to the rich [...]. This very change will bring with it a continual approach to equality of genuine comfort (Clark 1901).

In 2013, the economists Donald Boudreaux and Mark Perry noted that:

[A]ccording to the Bureau of Economic Analysis, spending by households on many of modern life's 'basics'-food at home, automobiles, clothing and footwear, household furnishings and equipment, and housing and utilities-fell from 53 percent of disposable income in 1950 to 44 percent in 1970 to 32 percent today (Boudreaux and Perry 2013).

It is a point which the economic historian Robert Fogel (1999) had made for a longer span. The economist Steven Horwitz summarizes the facts on labor hours required to buy a color TV or an automobile, and notes that:

[T] hese data do not capture [...] the change in quality [...]. The 1973 TV was at most 25 inches, with poor resolution, probably no remote control, weak sound, and generally nothing like its 2013 descendant [...]. Getting 100,000 miles out of a car in the 1970s was cause for celebration. Not getting 100,000 miles out of a car today is cause to think you bought a lemon (Horwitz 2013, 11). 
Nor in the United States are the poor getting poorer. Horwitz observes that:

[L]ooking at various data on consumption, from Census Bureau surveys of what the poor have in their homes to the labor time required to purchase a variety of consumer goods, makes clear that poor Americans are living better now than ever before. In fact, poor Americans today live better, by these measures, than did their middle class counterparts in the 1970s (Horwitz 2013, 2).

In the summer of 1976 an associate professor of economics at the University of Chicago had no air conditioning in his apartment. ${ }^{3}$ Nowadays many quite poor Chicagoans have it. The terrible heat wave in Chicago of July 1995 killed over 700 people, mainly low-income (Klinenberg 2003). ${ }^{4}$ Yet earlier heat waves in 1936 and 1948, before airconditioning was at all common, had probably killed many more. ${ }^{5}$

The political scientist and public intellectual Robert Reich argues that we must nonetheless be alarmed by inequality, Gini-coefficient style, rather than devoting all our energies to raising the absolute condition of the poor. "Widening inequality", he declares, "challenges the nation's core ideal of equal opportunity".

Widening inequality still hampers upward mobility. That's simply because the ladder is far longer now. The distance between its bottom and top rungs, and between every rung along the way, is far greater. Anyone ascending it at the same speed as before will necessarily make less progress upward (Reich 2014).

Reich is mistaken. Horwitz summarizes the results of a study by Julia Isaacs on individual mobility 1969-2005: "82\% of children of the bottom 20\% in 1969 had [real] incomes in 2000 that were higher than what their parents had in 1969. The median [real] income of those children of the poor of 1969 was double that of their parents" (Isaacs

\footnotetext{
${ }^{3}$ Horwitz 2013's Table 4 reports the percentage of poor households with various appliances: in 1971, 32 percent of such household had air conditioners; in 2005, 86 percent did.

${ }^{4}$ The 2003 heat wave in non-air-conditioned France killed 14,800 people, and 70,000 Europe-wide.

${ }^{5}$ Barreca and collaborators (2013) show the very large effect in the United States of air conditioning in reducing excess mortality during heat waves.
} 
2007, quoted in Horwitz 2013, 7). There is no doubt that the children and grandchildren of the English coal miners of 1937, whom Orwell describes "traveling" underground, bent over double walking a mile or more to get to the coal face, at which point they started to get paid, are much better off than their fathers or grandfathers. There is no doubt that the children and grandchildren of the Dust Bowl refugees in California are. Steinbeck chronicled in The grapes of wrath their worst and terrible times. A few years later many of the Okies got jobs in the war industries, and many of their children later went to university. Some went on to become university professors who think that the poor are getting poorer.

The usual way, especially on the left, of talking about poverty relies on the percentage distribution of income, staring fixedly for example at a relative "poverty line". As the progressive Australian economist Peter Saunders notes, however, such a definition of poverty "automatically shift upwards whenever the real incomes (and hence the poverty line) are rising" (Saunders 2013, 214). The poor are always with us, but merely by definition, the opposite of the Lake Wobegon effect-it is not that all the children are above average, but that there is always a bottom fifth or tenth or whatever in any distribution whatsoever. Of course.

The philosopher Harry Frankfurt noted long ago that "calculating the size of an equal share [of income in the style of poverty lines or Gini coefficients] is plainly much easier than determining how much a person needs in order to have enough"-"much easier" as in dividing GDP by population and reporting with irritation that some people earn, or anyway get, more (Frankfurt 1987, 23-24). It is the simplified ethics of the schoolyard, or dividing the pizza: "That's unfair". But as Frankfurt also noted, inequality is in itself ethically irrelevant: "economic equality is not, as such, of particular moral importance" (Frankfurt 1987, 21). In ethical truth we wish to raise up the poor, Joshua-Monk style, to "enough" for them to function in a democratic society and to have full human lives. It does not matter ethically whether the poor have the same number of diamond bracelets and Porsche automobiles as do owners of hedge funds. But it does indeed matter whether they have the same opportunities to vote or to learn to read or to have a roof over their heads. The Illinois state constitution of 1970 embodies the confusion between the condition of the working class on the one hand and the gap between rich and poor on the other, claiming in its 
preamble that it seeks to "eliminate poverty and inequality". ${ }^{6}$ We had better focus directly on what we actually want to achieve, which is equal sustenance and dignity, eliminating poverty, or what the economist Amartya Sen and the philosopher Martha Nussbaum call ensuring adequate capabilities. The size of the Gini coefficient or the share of the bottom 10 percent is irrelevant to the noble and ethically relevant purpose of raising the poor to a condition of dignity, Frankfurt's "enough".

Much of the research on the economics of inequality stumbles on this simple ethical point, focusing on measures of relative inequality such as the Gini coefficient or the share of the top 1 percent rather than on measures of the absolute welfare of the poor, on inequality rather than poverty, having elided the two. Speaking of the legal philosopher Ronald Dworkin's egalitarianism, Frankfurt observed that Dworkin in fact, and ethically, "cares principally about the [absolute] value of people's lives, but he mistakenly represents himself as caring principally about the relative magnitudes of their economic assets" (Frankfurt 1987, 34; italics added). Piketty himself barely gets around to caring about "the least well off" (p. 577; the last phrase in the last sentence of the book, though he does occasionally mention the issue in the body of the book, as on p. 480).

Dworkin and Piketty and much of the left commonly, in other words, miss the ethical point, which is the liberal, Joshua-Monk one of lifting up the poor. By redistribution? By equality in diamond bracelets? No: by the dramatic increase in the size of the pie, which has historically brought the poor to 90 or 95 percent of "enough", as against the 10 or 5 percent attainable by redistribution without enlarging the pie. The economic historian Robert Margo noted in 1993 that before the U.S.A. Civil Rights Act of 1964 "blacks could not aspire to high-paying white collar jobs" because of discrimination. Yet African Americans had prepared themselves, by their own efforts, up from slavery, to perform in such jobs if given a chance. "Middle-class blacks owe their success in large part to themselves", and to the increasingly educated and productive society they lived in. "What if the black labor force, poised on the eve of the Civil Rights Movement, was just as illiterate, impoverished, rural, and Southern as when Lincoln freed the slaves? [...] Would we have as large a black middle class as we do today? Plainly not" (Margo 1993, 68, $65,69)$.

${ }^{6}$ http://www.ilga.gov/commission/lrb/conent.htm 
Yet the left works overtime, out of the best of motives-and Piketty has worked very hard indeed-to rescue its ethically irrelevant focus on Gini coefficients and especially the disgraceful consumption of the very rich.

For the poor in the countries that have allowed the ethical change to happen, then, Frankfurt's "enough" has largely come to pass. "Largely", I say, and much more than alternative systems have allowed. I do not say "completely", or "as much as every honorable person would wish". But the contrast between the condition of the working class in the proudly "capitalist" United States and in the avowedly social-democratic countries such as the Netherlands or Sweden is not in fact very large, despite what you have heard from journalists and politicians who have not looked into the actual statistics, or have not lived in more than one country, and think that half of the American population consists of poor urban African-Americans. The social safety net is in practice rather similar among rich countries.

But the safety net, with or without holes, is not the main lift for the poor in the United States, the Netherlands, Japan, Sweden, or the others. The main lift is the Great Enrichment. Boudreaux noted that a literal billionaire who participated in a seminar of his did not look much different from an "impoverished" graduate student giving a paper about Gini coefficients.

In many of the basic elements of life, nearly every American is as well off as Mr. Bucks [his pseudonym for the billionaire]. If wealth differences between billionaires and ordinary Americans are barely visible in the most routine aspects of daily life, then to suffer distress over a Gini coefficient is to unwisely elevate ethereal abstraction over palpable reality (Boudreaux 2004).

Mr. Bucks undoubtedly had more houses and more Rolls-Royces than the graduate student. One may ask, though, the cheeky but always relevant question: So what?

The most fundamental problem in Piketty's book, then, is that the main event of the past two centuries was not the second moment, the distribution of income on which he focuses, but its first moment, the Great Enrichment of the average individual on the planet by a factor 
of 10 and in rich countries by a factor of 30 or more. The greatly enriched world cannot be explained by the accumulation of capital-as to the contrary economists have argued from Adam Smith through Karl Marx to Thomas Piketty, and as the very name "capitalism" implies. Our riches were not made by piling brick upon brick, bachelor's degree upon bachelor's degree, bank balance upon bank balance, but by piling idea upon idea. The bricks, BAs, and bank balances-the capital accumulations-were of course necessary, as was a labor force and the existence of liquid water. Oxygen is necessary for a fire. But it would be unenlightening to explain the Chicago Fire of October 8-10, 1871 by the presence of oxygen in the earth's atmosphere. Better: a long dry spell, the city's wooden buildings, a strong wind from the southwest, and Mrs. O'Leary's cow.

The modern world cannot be explained by routine brick-piling, such as the Indian Ocean trade, English banking, the British savings rate, the Atlantic slave trade, the enclosure movement, the exploitation of workers in satanic mills, or the original accumulation of capital in European cities, whether of physical or of human capital (see McCloskey 2010). Such routines are too common in world history and too feeble in quantitative oomph to explain the ten- or thirty- or one hundred-fold enrichment per person unique to the past two centuries. It was ideas, not bricks. The ideas were released for the first time by a new liberty and dignity, the ideology known to Europeans as "liberalism". The modern world was not caused by "capitalism", which is ancient and ubiquitous-quite unlike liberalism, which was in 1776 revolutionary. The Great Enrichment, 1800 to the present, the most surprising secular event in history, is explained instead by bettering ideas, sprung from liberalism.

Consider in light of the Great Enrichment one of Piketty's and the left's favorite suggestions for policy. Taxing the rich to help the poor seems in the first act a fine idea. When a bourgeois child first realizes how very poor people are in other neighborhoods she naturally wishes to open her purse to them, or still better Daddy's wallet. It is at such an age-16 or so-that we form our political identities, which like loyalties to football teams we seldom then revise in the face of later evidence. Our families, after all, are little socialist economies, with Mother as central planner. Let us remake society, the generous adolescent proposes, as one big family of 315 million people. Surely the remaking will solve the problem of poverty, raising up the poor by big amounts, 
such as the 20 or 30 percent of income stolen by the bosses. In an ancient society of slaves the slave-owning child had no such guilt, because the poor were very different from herself. But once the naturalness of hierarchy was questioned, as it was in the eighteenth century in northwestern Europe, and in the nineteenth century more generally, it seems obvious to adopt socialism. Ye cannot serve God and mammon ("mammon" is the Aramaic word for "money").

The equality of a home is natural, with one source of income-the father or, lately, the mother-and a task of "distributing" the proceeds. Papa might get more food if he is a hewer in a mine and needs the extra calories to get through a ten-hour shift at the coal face, but otherwise the distribution is naturally, and ethically, equal. Equality is natural to a home. The Swedish political motto from the 1920s on, folkhemmet, was "the national home". But a nation is not a home. In the Great Society-as, in advance of President Johnson, Hayek called it, meaning a big society as contrasted with a little band or a family-the source of income is not the father's pay packet but the myriad specialized exchanges with strangers we make every day. Equality of "distribution" is not natural to such a society, of 9 million in Sweden, and certainly not one of 315 million in the United States.

And in some important ways even French-style equality is improved by an ethic of markets. Free entry erodes monopolies that in traditional societies keep one tribe rich and the other poor. A market in labor erodes differentials among equally productive workers in cotton textiles, or indeed between on the one hand a professor who teaches with the same scant equipment that Socrates used-a place to draw diagrams, a stretch of sand in Athens, Greece or a whiteboard in Athens, Georgia, and a crowd of students-and on the other an airline pilot working with the finest fruits of a technological civilization. The pilot produces thousands of times more value of travel services per hour than a Greek steersman in 400 BCE. The professor produces if she is exceptionally lucky the same insight per student-hour as Socrates. But equality of physical productivity does not matter in a free, great society, a trading and mobile one. Entry and exit to occupations are what matter. The professor could in the long run have become an airline pilot, and the pilot a professor, which is enough to give even workers like the professor who have not increased in productivity in the past 2,500 years an equal share of the finest fruits. 
Having noted this highly egalitarian result of a society of markettested betterment, though, what about subsequent "distribution" of the fruits? Why shouldn't we-one might ask, who "we"?-seize the high incomes of the professor and the airline pilot and the heiress to the L'Oréal fortune and distribute them to dustmen and cleaners? The reply is that what people earn is not merely an arbitrary tax imposed on the rest of us. That is what an inequality within the little socialism of a household would be, Cinderella getting less to eat than her ugly sisters out of mere spite. Earnings, however, support an astonishingly complicated, if largely unplanned and spontaneous, division of labor, whose next move is determined by the differentials-the profit in trade or in occupation. If medical doctors make ten times more than cleaners, the rest of the society, which pays voluntarily for the doctors and cleaners is saying, "If cleaners could become doctors, viewing the matter in the long run, shift more of them into doctoring". If we reduce the Great Society to a family by taxing the rich we destroy the signaling. People wander between cleaning and doctoring without such signals about the value people put on the next hour of their services. Neither doctoring nor cleaning gets done well. The Great Society becomes the unspecialized society of a household, and if consisting of 315 million people it becomes miserably equal, and loses the massive gain from specialization and the accumulated ingenuity that are transmitted by education to a trade and by the steadily bettering robots (all tools, note, are robots) applied to each, the nail guns and computers that make master carpenters and master school teachers better and better at providing houses and educations to others.

Redistribution, although assuaging bourgeois guilt, has not been the chief sustenance of the poor. The social arithmetic shows why. If all profits in the American economy were forthwith handed over to the workers, the workers (including some amazingly highly paid "workers", such as sports and singing stars, and big-company CEOs) would be 20 percent or so better off, right now. But one time only. The expropriation is not a 20 percent gain every year forever, but merely this one time, since you cannot expropriate the same people year after year and expect them to come forward with the same sums ready to be expropriated again and again. A one-time expropriation raises the income of the workers by 20 percent, and then their income reverts to the previous level-or at best (if the profits can simply be taken over by the state without damage to their level, miraculously, and then are distributed to 
the rest of us by saintly bureaucrats without sticky fingers or favored friends) continues with whatever rate of growth the economy was experiencing (supposing, unnaturally and contrary to the evidence of communist experiments from New Harmony, Indiana to Stalinist Russia, that the expropriation of the income of capital will not reduce the rate of growth of the pie).

Or, to speak of expropriation by regulation, the imposing by act of Congress a ten-hour pay for eight hours of work would, again, raise the incomes of the portion of the working class that got it, one time, by 25 percent. It would do so in the first act, under the same, unnatural supposition that the pie was not thereby reduced, when the managers and entrepreneurs desert the now unprofitable activity. The redistribution sounds like a good idea, unless you reflect that at such rates the bosses would be less willing to employ people in the first place, and anyway those who did not get it (agricultural workers, for example) would find their real incomes reduced, not raised.

Here is another idea for income transfers, then: If we took away the alarmingly high share of U.S.A. income earned by the top 1 percent, which was in 2010 about 22 percent of national income, and gave it to the rest of us, we as The Rest would be 22/99, or a tiny bit under 22 percent better off. Or put it still another way. Suppose the profits were allowed to be earned by the people directing the economy, by the owner of the little convenience store in your neighborhood as much as by the malefactors of great wealth. But suppose the profit earners, out of a Gospel of Wealth, and following Catholic social teaching, decided that they themselves should live modestly and then give all their surplus to the poor. The economist David Colander declares that "a world in which all rich individuals [...] [believed] that it is the duty of all to give away the majority of their wealth before they die would be quite different from [...] our world" (Colander 2013, xi). But wait. The entire 20 percent would raise the incomes of the rest-many of them university professors getting Guggenheim fellowships or sweetly leftwing folk getting Macarthur "genius" awards-but by a magnitude nothing like the size of the fruits of modern economic growth. And even that calculation supposes that all profits go to "rich individuals".

The point is that 20 and 22 and 25 percent are not of the same order of magnitude as the Great Enrichment, which in turn had nothing in historical fact to do with such redistributions or charitable contributions. The point is that the one-time redistributions are two 
orders of magnitude smaller in helping the poor than the 2,900 percent Enrichment from greater productivity since 1800 . Historically speaking 25 percent is to be compared with a rise in real wages 1800 to the present by a factor of 10 or 30 , which is to say 900 or 2,900 percent. The very poor, in other words, are made a little better off by expropriating the expropriators, or persuading them to give all their money to the poor and follow Me, but much better off by coming to live in a radically more productive economy.

If we want to make the non-bosses or the poor better off by a significant amount, 2,900 percent beats a range from 20 to 25 percent every time. Chairman Mao's emphasis on class warfare spoiled what gains his Chinese Revolution had achieved. When his heirs shifted in 1978 to "socialist modernization" they (inadvertently) adopted markettested betterment, and achieved in thirty years a rise of Chinese perperson real income by a factor of 20-not a mere 20 percent but 1,900 percent. ${ }^{7}$ Deng Xiaoping's anti-equalizing motto was, "Let some people get rich first". It is the Bourgeois Deal: "You accord to me, a bourgeois projector, the liberty and dignity to try out my schemes in a voluntary market, and let me keep the profits, if I get any, in the first act-though I accept, reluctantly, that others will compete with me in the second. In exchange, in the third act of a new, positive-sum drama, the bourgeois betterment provided by me (and by those pesky, low-quality, pricespoiling competitors) will make you all rich". And it did.

Unlike China growing at 10 percent per year and India at 7 percent, the other BRIICS of Brazil, Russia, Indonesia, and South Africa have stuck with anti-neo-liberal ideas such as Argentinian self-sufficiency and 1960s British unionism and 1990s German labor laws and a misunderstanding of Korea's "export-led" growth. Indeed, the literature of the "middle-income trap", which speaks in particular of Brazil and South Africa, depends on a mercantilist idea that growth depends on exports, which are alleged to have a harder time growing when wages rise (see McCloskey 2006c). Policies to encourage this or that export depend, that is, on denying comparative advantage, and anyway focus on externals when what mainly matters to the income of the poor is domestic efficiency. Therefore the middle-income countries with market-denying laws, such as slowing entry to new business and onerously regulating old business, drag along at less than 3 percent growth per year per person-at which a mere doubling takes a quarter

\footnotetext{
${ }^{7}$ On 1978, see Coase and Wang 2013, 37.
} 
of a century and a quadrupling takes fifty years. Slow growth yields envy, as the economist Benjamin Friedman (2005) has argued, and envy yields populism, which in turn yields slow growth. That is the real "middle income trap". Getting out of it requires accepting, as Holland did in the sixteenth century and Britain in the eighteenth, and as China and India did in the late twentieth, the Bourgeois Deal.

Supposing our common purpose on the left and on the right, then, is to help the poor, as in ethics it certainly should be, the advocacy by the learned cadres of the left of equalizing restrictions and redistributions and regulations can be viewed at best as thoughtless. Perhaps, considering what economic historians now know about the Great Enrichment, but which the left clerisy, and many of the right, stoutly refuse to learn, it can even be considered unethical. The left clerisy such as Tony Judt or Paul Krugman or Thomas Piketty, who are quite sure that they themselves are taking the ethical high road against the wicked selfishness of Tories or Republicans or l'Union pour un Mouvement Populaire, might on such evidence be considered dubiously ethical. They are obsessed with first-act changes that cannot much help the poor, and often can be shown to damage them, and are obsessed with angry envy at the consumption of the uncharitable rich, of which they personally are often examples, and the ending of which would do very little to improve the position of the poor. They are very willing to stifle through taxing the rich the market-tested betterments which in the long run have gigantically helped the rest of us.

The productivity of the economy in 1900 was very, very low, and in 1800 even lower. The only way that the bulk of the people, and the poorest among them, were going to be made seriously better off was by making the economy much, much more productive. The share going to the workers was roughly constant (in one respect during the nineteenth and early twentieth century labor's share was rising, because land rent, once a third of national income even in Britain, fell in its share). The share was determined, as the economists such as the American J. B. Clark and the Swede Knut Wicksell put it in the late nineteenth century, by the marginal productivity of workers. And so according to the economists' argument even the poorest workers could be expected to share in the rising productivity-by those factors or 10 or 30 or 100 . And they did. The descendants of the horribly poor of the 1930s, for instance, are doing much better than their ancestors. Radically creative destruction piled up ideas, such as the railways creatively destroying 
walking and the stage coaches, or electricity creatively destroying kerosene lighting and the hand washing of clothes, or universities creatively destroying literary ignorance and low productivity in agriculture. The Great Enrichment-in the third act-requires not the accumulation of capital or the exploitation of workers but the Bourgeois Deal.

The left explains the inability of workers themselves to grasp the hard-left dogma that all employment is exploitation by saying that the workers are in the grip of false consciousness (see Lemert 2012, 21). If the Bourgeois Deal is sound, though, the falsity in consciousness is attributable not to the sadly misled workers but rather to the leftish clerisy themselves, and the politics is reversed. Workers of the world unite: demand market-tested progress under a régime of private property and profit-making. Still better, become bourgeois, as large groups of workers in rich countries do believe they have become, approaching 100 percent in the United States, measured by selfidentification as "middle class". It would then seem at least odd to call "false" a consciousness that has raised the income of poor workers in real terms by a factor of 30, as from 1800 to the present conservatively measured it has. If workers have been "fooled" by accepting the Deal, then for such a way of being fooled let us give two-and-a-half cheersthe deduction of half a cheer being because it's not dignified to be "fooled" by anything. Two-and-a-half cheers for the new dominance since 1800 of a bourgeois ideology and the spreading acceptance of the Bourgeois Deal.

On the next to last page of his book Piketty writes: "It is possible, and even indispensable, to have an approach that is at once economic and political, social and cultural, and concerned with wages and wealth". One can only agree. But he has not achieved it. His gestures to cultural matters consist chiefly of a few naively used references to novels he has read superficially, for which on the left he has been embarrassingly praised (Skwire and Horowitz 2014). His social theme is a narrow ethic of envy. His politics assumes that governments can do anything they propose to do. And his economics is flawed from start to finish.

It is a brave book. But it is mistaken.

\section{REFERENCES}

Aristotle. Politics. Trans. Benjamin Jowett.

https://ebooks.adelaide.edu.au/a/aristotle/a8po/book1.html (accessed Oct-2014). 
Baran, Paul, and Paul Sweezy. 1966. Monopoly capital: an essay on the American economic and social order. New York: Monthly Review Press.

Barreca, Alan, Karen Clay, Olivier Deschenes, Michael Greenstone, and Joseph S. Shapiro. 2013. Adapting to climate change: the remarkable decline in the U.S. temperature-mortality relationship over the 20th century. NBER Working Paper No. 18692. National Bureau of Economic Research, Cambridge, MA.

Bastiat, Frédéric. 1996 [1845]. Economic sophisms [trans. Arthur Goddard]. Irvingtonon-Hudson (NY): Foundation for Economic Education.

Boudreaux, Donald. 2004. Can you spot the billionaire? The Freeman, January 1.

Boudreaux, Donald. 2014. The consumption gap between the rich and the rest of us. Blog in Café Hayek, January 21, http://cafehayek.com/2014/01/the-consumptiongap-between-the-rich-and-the-rest-of-us.html (accessed November 2014).

Boudreaux, Donald, and Mark Perry. 2013. The myth of a stagnant middle class. Wall Street Journal, January 23.

Brennan, Geoffrey, Gordon Menzies, and Michael Munger. 2014. A brief history of equality. Working Paper No. 17, Economics Discipline Group, University of Technology Sydney Business School, Sidney.

http://www.uts.edu.au/sites/default/files/edg_wp17.pdf (accessed October 2014).

Carnegie, Andrew. 1889. Wealth. North American Review, (1891): June.

http://www.swarthmore.edu/SocSci/rbannis1/AIH19th/Carnegie.html

(accessed November 2014).

Clapham, J. H. 1922. Of empty economic boxes. Economic Journal, 32 (127): 305-314.

Clark, John Bates. 1901. The society of the future. The Independent, 53 (July 18): 16491651. Reprinted in Democracy and the gospel of wealth [1949], ed. Gail Kennedy. Boston: Heath, Problems in American Civilization, 77-80.

Coase, Ronald, and Ning Wang. 2013. How China became capitalist. Basingstoke (UK): Palgrave-Macmillan.

Colander, David. 2013. Introduction. To Gino Barbieri. 1940. Decline and economic ideals in Italy in the early modern era [Gli economici degli Italiani all'inizio dell-era moderna] [2013], translators S. Noto, and Marian Christina Gatti. Firenze: Leo S. Olschki Editore.

Deaton, Angus. 2013. The great escape: health, wealth, and the origins of inequality. Princeton: Princeton University Press.

Easterly, William. 2001. The elusive quest for growth: economists' adventures and misadventures in the tropics. Cambridge: MIT Press.

Ehrlich, Paul R. 1968. The population bomb. New York: Ballantine Books. Cited as "Revised" in reprint of 1975 by Jackson Heights, New York: Rivercity Press.

Ellenberg, Jordan. 2014. And the summer's most unread book is... Wall Street Journal, July 3.

Fisher, R. A. 1925. Statistical methods for research workers. Edinburgh: Oliver \& Boyd.

Fogel, Robert William. 1999. The fourth great awakening and the future of egalitarianism. Chicago: University of Chicago Press.

Fogel, Robert William. 2004. The escape from hunger and premature death 1700-2100. Cambridge: Cambridge University Press.

Frankfurt, Harry. 1987. Equality as a moral ideal. Ethics, 98 (1): 21-43.

Friedman, Benjamin M. 2005. The moral consequences of economic growth. New York: Knopf. 
Gazeley, Ian, and Andrew Newell. 2010. The end of destitution: evidence from British working households 1904-1937. Economics Department Working Paper Series 22010. University of Sussex, UK.

Harberger, Arnold C. 1954. Monopoly and resource allocation. American Economic Review, 44 (2): 77-87.

Hayek, Friedrich A. 1973. Law, legislation, and liberty, vol. 1: rules and order. Chicago: University of Chicago Press.

Hobsbawm, Eric. 2002. Interesting times: a 20th-century life. London: Allen Lane.

Horwitz, Steven. 2013. Inequality, mobility, and being poor in America. Unpublished paper, Department of Economics, St. Lawrence University, presented to conference on "Equality and Public Policy", Ohio University, Athens, OH, November 14-16, 2013.

Ibsen, Henrik. 1878. A doll house. In Ibsen: The complete major prose and plays [1965], editor and translator: R. Fjelde. New York: Penguin, 123-196.

Isaacs, Julia B. 2007. Economic mobility of families across generations. The Brookings Institution. www.brookings.edu/research/papers/2007/11/generations-isaacs (accessed November 2014).

Judt, Tony. 2010. Ill fares the land. London: Penguin.

Kirzner, Israel. 1979. Perception, opportunity and profit. Chicago: University of Chicago Press.

Klinenberg, Eric. 2002. Heat wave: a social autopsy of disaster in Chicago. Chicago: University of Chicago Press.

Lemert, Charles. 2012. Social things: an introduction to the sociological life [5th ed.]. Lanham (MD): Rowman \& Littlefield.

Margo, Robert A. 1993. What is the key to black progress? In Second thoughts: myths and morals of U.S. economic history, ed. Deirdre N. McCloskey. New York and Oxford: Oxford University Press, 65-69.

McCloskey, Deirdre N. 2006a. The bourgeois virtues: ethics for an age of commerce. Chicago: University of Chicago Press.

McCloskey, Deirdre N. 2006b. A solution to the alleged inconsistency in the neoclassical theory of markets: reply to Guerrien's reply [2006]. Post-Autistic Economics Review, 39 (1): 48-50.

McCloskey, Deirdre N. 2006c. Keukentafel economics and the history of British imperialism. South African Economic History Review, 21 (1-2): 171-176.

McCloskey, Deirdre N. 2010. Bourgeois dignity: why economics can't explain the modern world. Chicago: University of Chicago Press.

McCloskey, Deirdre N. Forthcoming (2015). Bourgeois equality: how betterment became ethical, 1600-1848, and then suspect. Chicago: University of Chicago Press.

Milanovic, Branko, Peter H. Lindert, and Jeffrey G. Williamson. 2011. Pre-industrial inequality. Economic Journal, 121 (551): 255-272.

Mueller, John. 1999. Capitalism, democracy, and Ralph's pretty good grocery. Princeton: Princeton University Press.

Nordhaus, William D. 2004. Schumpeterian in the American economy: theory and measurement. NBER Working Paper W10433. National Bureau of Economic Research, Cambridge, MA. 
Peart, Sandra J., and David M. Levy (eds.). 2008. The street porter and the philosopher: conversations on analytical egalitarianism. Ann Arbor: University of Michigan Press.

Piketty, Thomas. 2014 [2013]. Capital in the twenty-first century. Trans. Arthur Goldhammer. Cambridge: Harvard University Press. Original French edition: Éditions du Seuil, 2013.

Reich, Robert. 2014. How to shrink inequality. The Nation, May 6.

Ridley, Matt. 2014. The poor are getting less poor. Matt Ridley Online. June 05, 2014. http://www.rationaloptimist.com/blog/inequality-is-falling,-globally.aspx (accessed November 2014).

Sala-i-Martin, Xavier, and Maxim Pinkovskiy. 2010. Parametric estimations of the world distribution of income. VOX 22 January 2010.

http://www.voxeu.org/article/parametric-estimations-world-distribution-income (accessed November 2014).

Sala-i-Martin, Xavier. 2006. The world's distribution of income: falling poverty and convergence. Quarterly Journal of Economics, 121 (2): 351-397.

Saunders, Peter. 2013. Researching poverty: methods, results, and impact. Economic and Labour Relations Review, 24 (2): 205-218.

Skwire, Sarah, and Steven Horwitz. 2014. Thomas Piketty's literary offenses. The Freeman, September 11.

Smith, Adam. 1776. An inquiry into the nature and causes of the wealth of nations [Glasgow edition]. Campbell, Skinner, and Todd, eds. 2 vols. [1976, 1981]. Indianapolis: Liberty Classics.

Trollope, Anthony. 1867-1868. Phineas Finn: the Irish member. In Palliser novels [1982], ed. Jacques Bertoud. Oxford: Oxford University Press.

Tullock, Gordon. 1967. The welfare costs of tariffs, monopolies, and theft. Western Economic Journal, 5 (3): 224-232.

Waterman, Anthony M. C. 2012. Adam Smith and Malthus on high wages. European Journal of the History of Economic Thought, 19 (3): 409-429.

Whitford, David. 2005. The most famous story we never told. Fortune, September 19.

Williamson, Jeffrey G., and Peter H. Lindert. 1980. American inequality: $a$ macroeconomic history. New York: Academic Press.

Deirdre Nansen McCloskey is distinguished professor of economics and of history at the University of Illinois at Chicago and 2014 fellow of the Institute for Advanced Sustainability Studies (IASS), Potsdam, Germany.

Contact e-mail: <deirdre2@uic.edu> 